\title{
Intensity of affective experience is modulated by magnitude of intracranial electrical stimulation in human orbitofrontal, cingulate, and insular cortex
}

\author{
Jennifer Yih ${ }^{\mathrm{a}}$, Danielle E. Beam ${ }^{\mathrm{a}}$, Kieran C. R. Fox ${ }^{\mathrm{a}, \mathrm{b}}$, and Josef Parvizia,b, ${ }^{\mathrm{a}}$
}

${ }^{a}$ Department of Neurology and Neurological Sciences, Stanford University, Stanford, CA, U.S.A.

${ }^{\mathrm{b}}$ School of Medicine, Stanford University, Stanford, CA, U.S.A.

${ }^{\Psi}$ Corresponding author:

Josef Parvizi, 300 Pasteur Drive, Department of Neurology and Neurological Sciences, Stanford, CA, 94305. Phone: (650) 725-6648, Fax: (650) 498-6326, parvizi@stanford.edu

Abstract word count: 199

Main text word count: 5,737

Number of figures: 3

Number of tables: 3

Number of supplements: 2 


\begin{abstract}
The subjective and behavioral effects of intracranial electrical stimulation (iES) have been studied for decades, but there is a knowledge gap regarding the relationship between the magnitude of electric current and the type, intensity, and valence of evoked subjective experiences. We report on rare iES data from 18 neurosurgical patients with implanted intracranial electrodes in the orbitofrontal cortex (OFC), the insula (INS), and the anterior portion of cingulate cortex (ACC). ACC stimulation elicited somatic and visceral sensations, whereas OFC stimulation predominantly elicited olfactory and gustatory responses, and INS stimulation elicited a mix of effects involving somatic and visceral sensations, olfaction, and gustation. Further, we found striking evidence that the magnitude of electric current delivered intracranially correlated positively with the perceived intensity of subjective experience and the evoked emotional state, a relationship observed across all three regions. Finally, we observed that the majority of reported experiences were negatively-valenced and unpleasant, especially those elicited by ACC stimulation. The present study provides novel case studies from the human brain confirming that these structures contribute causally to the creation of affective states, and demonstrates a direct relationship between the magnitude of electrical stimulation of these structures and the qualia of elicited subjective experience.
\end{abstract}

Keywords: intracranial electrical stimulation; emotion; subjective experience; qualia; consciousness; neuromodulation; intracranial EEG; deep brain stimulation; affective neuroscience 


\section{Summary}

This study provides critical knowledge about the effect of electrical charge magnitude on the intensity of human subjective experiences and emotional states. We shed light on the fundamental relationship between the electrical (physical) state of cortical tissue and the modality and intensity of human (subjective) experience. As electroceutical interventions are increasingly employed to treat neurological and psychiatric disorders, these findings highlight the importance of electrical stimulation magnitude for eliciting specific changes in human subjective experience. 


\section{Introduction}

Emotion is an integral aspect of human experience, exerting a powerful influence over perception (Bar, Neta, \& Linz, 2006; Phelps, Ling, \& Carrasco, 2006), cognition (Fredrickson \& Branigan, 2005; Harmon-Jones, Gable, \& Price, 2012), and behavior (Baumeister, Vohs, DeWall, \& Zhang, 2007; Mauss, Levenson, McCarter, Wilhelm, \& Gross, 2005). Affect is typically characterized by arousal, or the intensity of the experience, and valence, or how pleasant or unpleasant a stimulus is (Russell, 1980; Watson, Clark, \& Tellegen, 1988). Beyond the clear importance of subcortical structures such as the amygdala, nucleus accumbens, and various brainstem nuclei, affective neuroscience has implicated a diverse range of cortical regions in affective processing, especially the anterior portion of the cingulate cortex (ACC), the orbitofrontal cortex (OFC), and the insula (INS; (Adolphs, Damasio, Tranel, Cooper, \& Damasio, 2000; Colibazzi et al., 2010; Dixon, Thiruchselvam, Todd, \& Christoff, 2017; Eisenberger, Jarcho, Lieberman, \& Naliboff, 2006; Eisenberger \& Lieberman, 2004; Gallo et al., 2018; Lamm \& Singer, 2010; Lewis, Critchley, Rotshtein, \& Dolan, 2006; Lieberman \& Eisenberger, 2015; Lindquist, Satpute, Wager, Weber, \& Barrett, 2015)). Functional neuroimaging has shown that these cortical structures are recruited during the appraisal (Dixon et al., 2017; Lamm, Batson, \& Decety, 2007), construction (Lindquist, Wager, Kober, BlissMoreau, \& Barrett, 2012), and regulation (Achterberg, van Duijvenvoorde, BakermansKranenburg, \& Crone, 2016; Buhle et al., 2014; Golkar et al., 2012; Ochsner \& Gross, 2005) of affective experience, in both healthy people (Damasio, 2003; Izard, 2009; Panksepp, 2003) and those with clinical mood disorders (Bremner et al., 2002; Davidson et al., 2002). 
The overwhelming majority of treatments for mood disorders in recent decades have used pharmacological interventions to modulate activity in these cortical regions. For instance, antidepressants and anxiolytics have been shown to decrease activity in the ACC and INS, which are hyperactive in patients with anxiety disorders (Barbas, Saha, Rempel-Clower, \& Ghashghaei, 2003; Etkin \& Wager, 2007; Mayberg et al., 1997; Paulus \& Stein, 2006; Simmons, Arce, Lovero, Stein, \& Paulus, 2009). Building on the discovery that intracranial electrical stimulation (iES) of the brain in neurosurgical patients alters both neural activity as well as subjective experience (Feindel \& Penfield, 1954; Mullan \& Penfield, 1959), clinicians are now seeking to go beyond purely pharmacological interventions by directly modulating affective experience in severe neuropsychiatric conditions using a variety of implanted and transcranial stimulation methods - hence the term electroceuticals (Famm, Litt, Tracey, Boyden, \& Slaoui, 2013). Even as the use of deep brain stimulation (DBS) and related intracranial interventions is becoming increasingly common in the treatment of neuropsychiatric conditions, however (Roy, Green, \& Aziz, 2018), initially promising clinical findings (Mayberg et al., 2005) have often failed to replicate (Morishita, Fayad, Higuchi, Nestor, \& Foote, 2014), prompting recognition that a more thorough and rigorous exploration of stimulation targets and parameters is necessary (Fins et al., 2017; Mayberg, Riva-Posse, \& Crowell, 2016). Yet overall, very little is known about the subjective emotional effects of electrical stimulation to most cortical regions. The few scattered case studies published to date suggest that the ACC, OFC, and INS yield distinctive affective responses following electrical stimulation: stimulation of the ACC has been reported to elicit changes in autonomic reactivity (Mangina \& Beuzeron-Mangina, 1996; Mulak, Kahane, Hoffmann, Minotti, \& Bonaz, 2008; Parvizi, Rangarajan, Shirer, Desai, \& Greicius, 2013; Pool \& Ransohoff, 1949) as well as emotional experiences of anxiety and fear (Mulak et al., 2008); 
stimulation of the OFC has elicited epigastric sensations (Mulak et al., 2008) and emotionallyvalenced smells and tastes (Fox et al., 2018); and INS stimulation has evoked anxiety and fear (Feindel \& Penfield, 1954; Mullan \& Penfield, 1959), pleasant affective experiences (Ostrowsky et al., 2000), cardiovascular changes (Oppenheimer, Gelb, Girvin, \& Hachinski, 1992), nausea (Feindel \& Penfield, 1954), and sensations involving olfaction and gustation (Ostrowsky et al., 2000).

As Guillory and Bujarski (2014) concluded in a recent review, extant findings from these case studies corroborate correlational neuroimaging data and confirm that the $\mathrm{ACC}, \mathrm{OFC}$, and INS play a crucial role in affective experience, but a better understanding is clearly needed of both the specific parameters ideal for the neuromodulation of affect (e.g., optimal frequency, magnitude, and duration), as well as the wider effects of focal stimulation on distributed brain networks (Alhourani et al., 2015). Moreover, the question of the ideal neuroanatomical location of stimulation for eliciting a specific effect on emotional state remains virtually unexplored. As a first step toward addressing these outstanding questions, here we present rare data from a sizable cohort of 18 neurosurgical patients with intracranial electrodes implanted in the ACC, OFC, and INS. Using archival reports from routine functional mapping sessions conducted at the bedside, we investigated the effects of anatomical location and intensity of intracranial electrical charge on the modality and perceived intensity of affective experience.

Based on our own prior work suggesting that increased iES current magnitude yields corresponding increases in the intensity of elicited visual experiences (Winawer \& Parvizi, 2016), we hypothesized that a similar positive relationship might exist between current magnitude and the intensity of affective experiences. We also sought to clarify whether iES of specific regions or subregions might show category-specific specialization. 


\section{Methods and Materials}

\section{Patient Characteristics}

Data were drawn from a pool of 129 patients admitted to the Stanford Hospital for invasive monitoring of medically refractory epilepsy. We only included cases where 1) focality of seizures was confirmed with initial intracranial EEG findings, 2) functional mapping had been applied to at least one of our three cortical regions of interest (ROIs), 3) stimulation parameters had also been systematically varied, and 4) post-operative CT and pre-operative MRI scans were available for the precise reconstruction of electrode locations. Ultimately, our sample consisted of 18 patients ( 8 female) with 140 electrodes of interest implanted in the ACC, OFC, and INS where stimulation parameters (i.e., amplitude and/or frequency) were systematically varied (Figure 1). The research was approved by the Stanford University Institutional Review Board.

\section{Regions of Interest (ROIs)}

We chose to explore effects of iES in three cortical regions unambiguously involved in human affect: the ACC, OFC, and INS (Figure 2A). As the present study was retrospective, it was not designed to explore the effects of iES across the entire extent of the ROIs or comprehensively throughout the entire brain. Rather, the sites available in each region were chosen as preliminary samples to study the relationship between anatomy, electrical charge, and affective experience.

Notably, the amygdala is near epileptic tissue, or itself pathological, in the overwhelming majority of our patients. We therefore did not include effects of amygdala stimulation in our current report. In the 18 patients included in the present study, ACC, OFC, and INS structures were free of clinical seizures or electrographic ictal activity.

\section{Procedures}


Electrode placement and localization. Patients were implanted with either subdural grid/strip electrode arrays $(n=5)$, depth electrodes $(n=11)$, or a mix of both $(n=2)$. Placement of all electrodes (AdTech Medical Instruments; Racine, WI) was determined strictly according to clinical criteria. To precisely establish electrode locations for each patient, electrodes were localized in the subject's own native anatomical space using a post-operative CT scan and a preoperative T1-weighted MRI scan. To pool results for visualization purposes, electrodes in subject-specific space were normalized to Montreal Neurological Institute (MNI) space and displayed on a standard brain template using the FreeSurfer Software Suite (Reuter, Schmansky, Rosas, \& Fischl, 2012). For certain electrodes in ACC and INS, which did not appear in the correct ROI after normalization to MNI space, we manually corrected electrode locations to accurately reflect actual electrode placement in subject-specific anatomy.

Intracranial Electrical Stimulation (iES). Cortical mapping was undertaken as part of a routine clinical mapping procedure at the Stanford University Medical Center. The rationale for this practice is to determine the precise location of epileptic tissue in the patient's brain. Initial pulses were delivered with low intensity to test if the stimulated tissue evokes any of the patient's typical seizure auras.

Across patients, we identified 65 electrodes where subjective affective experiences were elicited by iES ("hot spot" electrodes) during routine functional mapping sessions (Figure 1 and Figure 2A). Notably, stimulation of right OFC elicited more affective experiences than left OFC stimulation, due to the fact that $65 \%$ of OFC electrodes were located in the right hemisphere (Figure 1). Indeed, there were no hemispheric differences in the relative frequencies of hot spot electrodes in OFC $\left(\chi^{2}(1)=0.02, p=.89\right)$. Moreover, the majority of ACC $(58 \%)$ and INS $(53 \%)$ hot spot electrodes were located in the left hemisphere. Given that there were no hemispheric 
difference in the relative frequencies of hot spot electrodes in $\operatorname{ACC}\left(\chi^{2}(1)=1.10, p=.29\right)$ or in INS $\left(\chi^{2}(1)=0.48, p=.49\right)$, we projected all electrodes in these ROIs to the left hemisphere.

Stimulations were always applied with charge-balanced pulses and within the safe limits of charge density. Bipolar iES was delivered at these 65 unique electrode sites using an alternating square wave current applied across two adjacent electrodes with a pulse width of 200$300 \mu \mathrm{s}$. Further details of stimulation methods and parameters are described extensively in our prior research (Foster \& Parvizi, 2017; Parvizi et al., 2013).

We remind the reader that, due to the clinical nature of bedside electrical stimulation procedures, the present study was a retrospective archival report of clinical data obtained during routine bedside brain mapping procedures performed in 18 patients where stimulation parameters (current magnitude or frequency) were systematically varied within each patient (for clinical reasons) while probing subjects' verbal reports. Given its retrospective nature, the present study does not describe an experimental investigation that methodically titrated parameters of iES and sham stimulation across patients who shared identical coverage. Nonetheless, highlighting the effect of anatomical specificity in millimeter space, while also addressing the relationship between the effect of electrical dose and the intensity of subjective experience.

Evaluating subjective effects of stimulation. We considered the effect of stimulation to be valid only if: 1) the tissue stimulated was not determined to be epileptic; 2) stimulation at a given site did not result in seizures or after-discharges; and 3) sham stimulations did not lead to similar effects. Following iES or sham stimulation, patients were asked standardized questions probing if any experiences were evoked (e.g., "Did you notice anything?”, or “Any change?”). As needed, follow-up questions were asked to further clarify the character of reported effects (e.g., “Is it something you would like more or less of?", or "Is it something you would prefer to 
approach or avoid?”). Specific iES parameters and elicited subjective experiences (or lack thereof) were logged for each stimulation. Raters (J.Y. and D.E.B.) viewed and coded digitized iES reports and video-EEG recordings to confirm results.

Reported affective experiences were classified within the following data-driven categories: 1) sensations involving smell, taste, or both; 2) visceral sensations (e.g., sensations in the gut or upper chest; feelings of changes in heart rate); and 3) neither olfactory/gustatory nor visceral/somatic sensations, but rather, affective experiences devoid of any particular sensory content. Notably, all subjective experiences, including olfactory, gustatory, and visceral sensations, were considered affective. Some of these sensations occurred with additional experiential qualities (e.g., anxiety that involved chest sensations related to breathing), whereas some experiences were completely devoid of any sensory content (e.g., anxiety without any reported visceral sensations). Prior research has uncovered close links between olfaction/gustation and affective processing (Gottfried \& Zald, 2005; Jabbi, Swart, \& Keysers, 2007; Rolls, 2000; Royet, Plailly, Delon-Martin, Kareken, \& Segebarth, 2003; Zald \& Pardo, 1997), and visceral/somatic sensations are commonly considered a defining component of emotion, especially with respect to the physiological elements of affect (Izard, 2010; Mulligan \& Scherer, 2012). Indeed, some research suggests that somatic sensations play an integral, causal role in emotion (Critchley \& Garfinkel, 2017; Wilson-Mendenhall, Barrett, \& Barsalou, 2013), though the present study was not designed to investigate the temporal dynamics of emotion generation. To characterize an effect as an olfactory, gustatory, visceral, or bodily sensation, we relied upon verbal reports from patients describing each effect (see Table 2 for a general summary of reported effects for each patient). Alterations in subjective experience following 
manipulation of stimulation parameters were classified as changes in: 1) intensity; 2) valence; or 3) any other quality aside from intensity or valence.

In addition to classifying effects based on modality and how subjective experience was modulated, we classified the valence of effects within four categories: 1) negatively valenced or unpleasant experiences; 2) positively valenced or pleasant experiences; 3) mixed valence experiences that involved both negative and positive qualities; or 4) unclear, which typically indicated a lack of information from the patient's verbal report.

Controlling for potential confounds. To account for the confounding effects of any ictal phenomena, we ensured that none of the patients had an epileptic focus within, or required resection of, stimulated ROIs. Second, we ensured that data from any electrodes determined to be in the epileptic zone were excluded from all analyses. Finally, some patients had electrode grids placed over the ventral surface of the orbitofrontal cortex; any smell-related effects elicited by stimulation of electrodes along the midline of the ventral surface were excluded from all analyses as potentially confounded by stimulation of the olfactory nerve (for further details, see (Fox et al., 2018)).

To control for potential demand characteristics, occasional sham stimulations were randomly administered. During these sham stimulations, the clinician behaved exactly as during veridical stimulation, continuing to adjust settings on the stimulator and press the same buttons while asking the same standardized questions about any changes in subjective experience - the only difference being that no electrical current was actually delivered. Because some patients had few electrodes in the ROIs and received correspondingly few administrations of iES, sham stimulations were only delivered in 11 patients, rather than every patient in the sample. In general, given the retrospective nature of our data, we acknowledge that there is a possibility of 
sample bias, for instance with respect to anatomical sampling. However, no bias in subjective reports is to be expected, as all patients were asked the same set of standardized questions after each iES or sham stimulation.

Statistical Analyses. Chi-squared tests of independence were used to test for differences in frequency among specific modalities of experience for each ROI, as well as differences in frequency among valence-specific effects of electrical stimulation to each ROI. All statistical analyses were conducted in the $R$ programming environment (Version 3.4.4; (Team, 2018)).

\section{Results}

\section{Region-Specific Modalities of Elicited Affective Experiences}

We found that the type of affective experience elicited by iES was dependent on the region stimulated (Figures $2 \mathrm{~B}$ and $2 \mathrm{C}$ ). ACC stimulations elicited responses that were largely related to the autonomic nervous system and the body. Specifically, ACC stimulation involved significantly more visceral/somatic sensations (75\%) compared to other modalities of experience $\left(\chi^{2}(2)=12.13, p=.002 ; \phi=0.50\right)$, and never resulted in smell or taste responses. In contrast, the majority of subjective experiences evoked by OFC stimulation involved olfactory and gustatory content (75\%), and only a minority of elicited responses involved visceral/somatic sensations (25\%). The frequencies for each experiential modality elicited by OFC stimulation were significantly different $\left(\chi^{2}(2)=12.13, p=.002\right)$, and the size of the effect was large $(\phi=$ 0.50). Finally, a large proportion of responses elicited by INS stimulation involved visceral/somatic sensations $(62 \%)$, whereas only a minority of responses $(31 \%)$ involved olfactory/gustatory sensations. These differences in modality frequencies were significant $\left(\chi^{2}(2)\right.$ $=6.37, p=.041 ; \phi=0.35)$. 
In each subregion, the anatomical specificity of the evoked responses was specific within a 5 to 10 millimeter window around the stimulated electrode, as previously reported for ACC stimulations (Parvizi et al., 2013). For instance, after moving the site of stimulation by 5 to 10 $\mathrm{mm}$, the effect of stimulation either disappeared or changed to another domain (Tables 3 and 4).

Extending beyond sensations, four patients reported affective experiences devoid of sensory content (i.e., neither olfactory/gustatory nor visceral/somatic sensations). These subjective reports reflected what is known as the purely "experiential" or "feeling" component of emotional states (Izard, 2009). Subject 5 reported a "scared feeling” akin to fear with $4 \mathrm{~mA}$ of left INS stimulation, whereas both Subject 13 (left ACC) and Subject 18 (right ACC) reported experiences of anxiety and fear upon ACC stimulation at various magnitudes (Table 3). In addition to reports of negative emotion, Subject 2 reported an "aroused" and "sexually excited" feeling at $4 \mathrm{~mA}$ of stimulation to one left ACC electrode pairing.

Indeed, two male subjects reported feelings of sexual euphoria upon stimulation of the ACC (Table 3). As described above, Subject 2 reported a purely experiential effect of stimulation with $4 \mathrm{~mA}$ of current to a left ACC electrode pairing, and this affective experience was qualitatively different than the one elicited by stimulation to a neighboring, more anterior ACC site, which evoked the sensation of having an erection (albeit without any concomitant motor effects). Strikingly, Subject 3 also reported a "very sexually aroused" feeling with $5 \mathrm{~mA}$ of right ACC stimulation; stimulation at this site also elicited visceral/somatic sensations.

Visual inspection of electrode coverage in the INS suggests that, across subjects, we had three clusters of electrodes within this region. We more closely examined the stimulations within each of these clusters to determine if each cluster was implicated in specific modalities of subjective experience. First, upon stimulation of the two most anterior INS electrodes in our 
sample (purple circles, Figure 2C), fear was reported. Second, in our three most superior INS electrodes (Figure 2C), effects related mostly to taste and smell (blue circles), but also heart rate (green circle), were reported, implicating this region in both sensory and also non-sensory experiences. Third, in the largest cluster of electrodes, which extended from middle to posterior insula along its ventral aspect (Figure 2C), we observed smell and taste sensations across two patients as well as reports of anxiety from two patients and of nausea from one patient.

\section{Changes in Perceived Intensity with Changes in Stimulation Magnitude}

Our main results are presented in the form of a comprehensive table including all the electrode pairs whose stimulation led to reportable changes in the sensory, visceral, or purely affective domain (Table 3). Upon closer examination of the subjective reports, we found a striking pattern. Among the 65 electrode sites where affective experiences were elicited by DES and where stimulation magnitude was also systematically varied (Figure 2A), changes in stimulation magnitude always elicited changes in perceived intensity: stimulation magnitude and perceived intensity exhibited a positive correlation in all cases: i.e., increases in stimulation magnitude were associated with increased intensity of subjective experience, and decreased stimulation magnitude corresponded with decreases in perceived intensity. In addition to the detailed findings for each subject presented in Tables 3 and 4, a few examples are especially noteworthy. For instance, Subject 17 reported fear and the sensation of a "shock in my heart, out of my mouth, and down my arms" at $50 \mathrm{~Hz} / 5 \mathrm{~mA}$ stimulation of left ACC that became less intense when stimulation amplitude was reduced to $50 \mathrm{~Hz} / 2 \mathrm{~mA}$. With stimulation to the right OFC, Subject 4 reported a slight feeling of anger at $50 \mathrm{~Hz} / 5 \mathrm{~mA}$ of stimulation that became a very upset feeling paired with bodily changes, including crying, at $50 \mathrm{~Hz} / 7 \mathrm{~mA}$ of stimulation. In 
another example, Subject 13 reported anxiety that "stopped my breath" at $50 \mathrm{~Hz} / 6 \mathrm{~mA}$ of right INS stimulation that became more intense when stimulation amplitude was increased to $8 \mathrm{~mA}$. Importantly, though the majority of reported effects were elicited by a change in the amplitude of electrical charge, there were several instances across four subjects in which the frequency of stimulation was changed. In those cases, we observed changes in the modality and intensity of subjective experience with increased frequency (Supplemental Material Tables 1 and 2). In general, as both frequency and amplitude per trial were increased, perceived intensity also increased. Moreover, there were instances when subjective experience was seemingly intensified solely by increases in frequency. For example, with stimulation to left OFC, Subject 10 experienced a neutral smell with a reported intensity of $30 \%$ that became a bad smell with $50 \%$ intensity when frequency was increased from 10 to $20 \mathrm{~Hz}$, despite the fact that the charge per trial actually decreased (50 to $20 \mu \mathrm{C})$.

\section{Valence of Elicited Affective Experiences}

Across all regions of interest, 58\% of reported subjective affective experiences were negatively valenced and unpleasant, whereas $15 \%$ of experiences were positive and pleasant. These results are consistent with nearly one hundred years of intracranial stimulation research, which has found that, for reasons unknown, negatively-valenced experiences are elicited with far greater frequency than positively-valenced experiences (Guillory \& Bujarski, 2014; Selimbeyoglu \& Parvizi, 2010). Additionally, 9\% of elicited effects were classified as mixed affective experiences that involved both pleasant and unpleasant qualities. For example, Subject 1 reported a "sickening sweet" smell that we coded as both negative and positive in valence.

Finally, we were unable to classify the remaining $17 \%$ of affective experiences based on valence; these experiences all involved smell and taste sensations that were not specifically probed on 
valence, and we were unable to infer the valence of the experience based on the available subjective reports.

Focusing on each region of interest, ACC stimulation elicited negative affective experiences significantly more often than positively-valenced effects or mixed-valence experiences $\left(\chi^{2}(3)=15.66, p=.001 ; \phi=0.57\right)$. Notably, stimulation of more posterior regions of the ACC elicited pleasant affective experiences, whereas unpleasant affective effects were elicited with stimulation across ACC (Figure 3). Though approximately half of the affective experiences elicited by OFC stimulation (50\%) and by INS stimulation (47\%) were unpleasant, there were no significant differences between the frequencies of each valence category for either OFC stimulation $\left(\chi^{2}(3)=5.28, p=.15\right)$ or INS stimulation $\left(\chi^{2}(3)=2.17, p=.54\right)$.

In a small number of stimulated electrodes $(9 \%)$, changes in valence occurred along with changes in perceived intensity. Subject 15 was an especially compelling case study, as she reported a chocolate taste at lower intensity which became a distasteful "bad" chocolate taste with increased dose and duration of stimulation to the same electrode pairing (Supplemental Material Table 1). In one instance, Subject 15 even made a disgusted expression with her face, which had been neutral in prior stimulations (Movie 1). Emotional expression is considered to be a more objective component of emotion compared to the subjective component of experience.

\section{Discussion}

Prior observations of affective experience induced by the electrical stimulation of cortical structures have tended to be restricted to small samples and isolated brain regions (Caruana et al., 2018; Feindel \& Penfield, 1954; Fox et al., 2018; Inman et al., 2018; Mangina \& BeuzeronMangina, 1996; Mulak et al., 2008; Mullan \& Penfield, 1959; Oppenheimer et al., 1992; Ostrowsky et al., 2000; Parvizi et al., 2013; Pool \& Ransohoff, 1949). Though previous studies 
have specifically documented the subjective qualia of these affective experiences (Halgren, Walter, Cherlow, \& Crandall, 1978), to our knowledge, no previous study has systematically investigated the effect of varying stimulation parameters on these experiences. Building upon these pioneering investigations, here we explored how systematically varying the anatomical location and stimulation parameters of $\mathrm{iES}$ throughout the human brain relates to the modality and intensity of elicited affective experiences.

Our central finding, that current magnitude correlates with subjective intensity, parallels our previous observations of a clear relationship in the primary visual cortex between the magnitude of electrical stimulation, the size of cortical area being activated, and the size of perceived visual phosphenes (Winawer \& Parvizi, 2016) - a finding that was recently replicated (Bosking et al., 2017). The present study extends this research to so-called "limbic" structures and demonstrates a compelling relationship between stimulation magnitude and the intensity of affective experiences, not merely simple visual phenomena such as phosphenes.

Although this finding is intuitive and might appear obvious in hindsight, the extant literature has, to our knowledge, never demonstrated a relationship between the magnitude of electrical charge and the intensity of purely subjective experiences such as emotion. Some limited research has discussed the effects of increasing stimulation magnitude on other components of emotion - namely, the autonomic (Inman et al., 2018; Mangina \& BeuzeronMangina, 1996) and expressive components (Fried, Wilson, MacDonald, \& Behnke, 1998; Sperli, Spinelli, Pollo, \& Seeck, 2006) - but has been silent on the topic of truly subjective and experiential aspects of affective experience. Indeed, although increasing the amplitude of amygdala stimulation has elicited corresponding increases in physiological arousal (Inman et al., 2018), greater amygdala stimulation generally had no discernible relationship with subjective 
emotional experience. Our study therefore represents the first demonstration of a consistent positive relationship between stimulation magnitude and the perceived intensity of affective experience.

It is important to note, however, that all of our selected ROIs represent relatively large swathes of cortex, and none of these regions is homogenous at the cytoarchitectonic or functional level (Craig, 2009; Kringelbach, 2005; Vogt, Berger, \& Derbyshire, 2003). Although our relatively small number of electrodes precludes venturing any strong inferences about subregional specialization, some interesting trends are worth noting. For instance, different effects of stimulations across the three ROIs clearly suggest that the three separate structures are involved in distinct functions in the service of creating affective states. Moreover, there could also be subregional specialization within each of the ROIs. For instance, the two "pure" (i.e., devoid of specific sensory content) affective experiences we observed in the insula were located in the far anterior insular cortex, whereas more concrete visceral/somatic effects tended to cluster in the mid/posterior regions (Figure 2C). These findings are consistent with models of insular function positing a rostrocaudal gradient with primary interoceptive cortex in posterior aspects gradually transitioning to higher-level viscero-affective integration in the most anterior portions (Craig, 2009). Similarly, the handful of integrative, higher-level viscerosomatic experiences elicited in the OFC were at the most anterior electrodes, whereas more basic, unimodal olfactory and gustatory experiences predominated in the mid-to-posterior electrode sites (Figure 2C). Again, this trend (if robust) is consistent with a posterior-anterior functional gradient of simpler to more complex and integrative processing (Fox et al., 2018; Kringelbach, 2005). Some intriguing trends were also apparent with respect to valence: positively-valenced effects tended to cluster in the posterior $\mathrm{ACC}$, the right $\mathrm{OFC}$, and the ventral-anterior aspect of the insula 
(Figure 3). Although these trends are based on relatively few electrodes and their significance remains unclear, they suggest patterns of regional specialization that could be further explored and refined in larger cohorts (Guillory \& Bujarski, 2014). In the OFC at least, they complement and are consistent with the findings from a meta-analysis of 65 neuroimaging studies (Wager, Phan, Liberzon, \& Taylor, 2003) as well as our recent report of the left-lateralization of negatively-valenced effects induced by iES (Fox et al., 2018). Nonetheless, given inconsistencies in the literature on lateralization and affect, a meta-analysis spanning across method types is warranted to draw strong conclusions regarding the lateralization of valence.

Although much of the recent literature on the neural correlates of consciousness has focused on high-frequency electrical activity (Koch, Massimini, Boly, \& Tononi, 2016), our data suggest that subjective experiences can be elicited by simulation of specific sites within the human brain at frequencies significantly below the gamma $(>40 \mathrm{~Hz})$ range. Our preliminary results are consistent with several previous investigations showing that low-frequency stimulation may perturb subjective affective experience (Halgren et al., 1978; Pugnaghi et al., 2011), but more systematic work is needed to build upon the present study.

Our finding that ACC stimulation in two of our subjects elicited pleasurable feelings of sexual arousal is consistent with prior research implicating the cingulate cortex in sexual behaviors in healthy adults (Georgiadis \& Kringelbach, 2012; Ortigue, Bianchi-Demicheli, Patel, Frum, \& Lewis, 2010) and patient populations (Devinsky, Morrell, \& Vogt, 1995). Most past research has relied upon neuroimaging methods involving heterosexual males (Georgiadis \& Kringelbach, 2012), however, and our observations of sexual euphoria elicited by ACC stimulation also came from two single male subjects; further research is therefore needed to replicate these effects in males and explore whether they extend to female participants as well. 
Taken together, the present study represents an important step forward in the investigation of how modulating the amount of electrical charge may influence human affective states. Although it is apparent that such research can only be investigated in human subjects that are able to share their subjective experiences, we are mindful of several limitations of the present study's invasive intracranial approach.

The first limitation of our study is that our data are derived from patients with intractable epilepsy, which is a heterogeneous disease with variable severity, clinical appearance, and pathogenic mechanisms. At one end of the spectrum, severe epilepsy syndromes are hallmarked by multifocal epileptiform discharges, abnormal baseline brain activity, severe cognitive impairment, and behavioral regression. At the other end of the spectrum, focal epilepsies are seen in high-functioning adult patients who have normal intelligence and only localized abnormalities in affected brain structures. We mitigated the effect of epilepsy by recruiting patients in whom the focality of seizures was confirmed with initial intracranial EEG findings. In these cases, as we have recently reported (Parvizi \& Kastner, 2018), only a minority of electrodes show epileptic activity, with over $80 \%$ of implanted electrodes showing no epileptic activity. To minimize the potentially confounding effects of epileptic abnormalities, we included only those subjects in whom the three ROIs were void of epileptic abnormality and seizures. Furthermore, to minimize the effect of postictal state in our observations, clinical electrical stimulation procedures were performed several hours outside the window of seizures. Lastly, and perhaps most importantly, the reliability of our findings can be demonstrated by showing that the observed findings are anatomically and functionally consistent across patients with different types of epilepsy and variable seizure foci. 
The second limitation of our study is that we used an archival method that does not permit for a methodologically rigorous study of the relationship between different parameters of iES and standardized questionnaires probing subjective reports in each individual patient. For instance, in ideal conditions, we would have relied upon a systematic experiment across all patients that used random sequences of $\mathrm{iES}$ and sham stimulations, with $\mathrm{iES}$ stimulations delivered at randomly varying levels of electrical charge. However, such experiments are difficult, if not impossible, to perform in patient populations because of clinical safety concerns as well as severe time constraints in the clinical setting. In our report, we relied on clinical bedside observations throughout the last 10 years, carefully selecting those cases in which the clinicians had performed clinical bedside electrical stimulation procedure with different frequencies or amplitudes in one of the three ROIs. In these clinical procedures, for safety reasons, we aimed to keep the number of stimulations at a given site to the bare minimum. Therefore, though retrospective and largely descriptive in nature, our findings represent a unique and rare dataset on electrical stimulation of human brain structures. We hope that our findings will motivate future research to further examine the relationship between current amplitude or frequency and various aspects of subjective experience.

The third limitation of our study pertains to its "corticocentric" approach (Parvizi, 2009). We were not able to investigate the many subcortical structures known to play crucial roles in affect. There have been isolated case reports of direct electrical stimulation to subcortical areas eliciting diverse (and often intense) affective experiences (Guillory \& Bujarski, 2014; Inman et al., 2018; Selimbeyoglu \& Parvizi, 2010). Our focus on cortical structures was a result of the limitations of our sample and electrode implantations, and is by no means intended to minimize the role of subcortical regions in complex affective states (Parvizi, 2009). More systematic 
investigations of affective responses to electrical stimulation in human subcortical regions would be a welcome addition to this emerging field.

Finally, the present study was limited in that we used two different electrode types for iES, i.e., subdural grids and strips versus depth electrodes. Subdural electrodes rest upon and stimulate the cortical surface. In contrast, depth electrodes are inserted deep into grey matter structures. These different electrode types likely exhibit distinct patterns of current flow, which could potentially confound our findings. Nonetheless, our central finding of the relationship between stimulation magnitude and the intensity of subjective affective experience remained consistent across both types of electrodes (Figure 2A), suggesting that this was not the case in our sample. Further research, however, is clearly needed to better understand the biophysics of electrical stimulation in the human brain (Buzsáki, Anastassiou, \& Koch, 2012; Parvizi \& Kastner, 2018).

Limitations of our approach aside, several aspects of the present study are noteworthy: first, we relied solely on subjective qualitative reports of experience and allowed subjects to openly express their affective states without asking them to fill out questionnaires. Although this method did not allow us to quantitatively measure the precise effects of stimulation, a freeresponse approach allowed our subjects to openly express themselves and use their own natural words to denote changes in intensity or other aspects of their experiences. Moreover, for each electrode of interest, we evaluated how experiences changed as stimulation magnitude was modulated. With changes in intensity, subjects often specifically stated that a previously reported effect became stronger or weaker, despite being completely blinded to stimulation magnitude. In light of the open nature of self-report and the enormous range of possible subjective experience, it is remarkable how individual subjective reports across multiple subjects fell within specific 
domains of affective experience, and that these domains were largely determined by anatomical location and predictably modulated by changes in iES magnitude.

Another notable feature of the present study is its focus on within-subject changes in affective experience during iES. There are critical individual differences in electrical excitability of tissue (Krause \& Cohen Kadosh, 2014), interoceptive awareness (Craig, 2004; Garfinkel, Seth, Barrett, Suzuki, \& Critchley, 2015), and other factors likely to confound between-subject investigations of this kind. However, given our within-subjects approach, any bias introduced by inter-subject variability should not have influenced our primary finding of the correlation between the intensity of subjective experiences elicited by iES of varying magnitude.

Our observations remind us of both the promise and perils of the ongoing efforts to tune and manipulate human emotional experience through the use of technological devices. As implanted electroceutical interventions are increasingly employed to treat neurological and psychiatric conditions (Roy et al., 2018), we hope that our findings will have useful implications for clinicians aiming to modulate emotional experience with intracranial electrical devices. 


\section{Acknowledgments}

The authors thank the EEG technicians in the Stanford Epilepsy Monitoring Unit (Harinder Kaur, Luida Schomacher, and Thi Pham) for their invaluable assistance during the clinical functional mapping procedures; neurosurgeons Dr. Jaimie Henderson and Dr. Casey Halpern for their role in the implantation of intracranial electrodes; Omri Raccah for assistance with data visualization; Lin Shi for assistance with transforming coordinate data from subject-specific to standard MNI space; and Alexander O. King for assistance with creating video footage. J.Y. was supported by the National Science Foundation (NSF) grant BCS-1756466; D.E.B. was supported by the Stanford Undergraduate Advising and Research Student Grant; K.C.R.F. was supported by a postdoctoral fellowship from the Natural Sciences and Engineering Research Council (NSERC) of Canada; and J.P. acknowledges support from NSF grant BCS-1756466. 


\section{Financial Disclosures}

All authors (J.Y., D.E.B., K.C.R.F., and J.P.) have no financial disclosures or conflicts of interest to declare. 
Table 1. Descriptive statistics on intracranial electrical stimulation (iES) parameters of interest.

\begin{tabular}{c|cccc} 
ROI & $\begin{array}{c}\text { Amplitude } \\
\text { range }\end{array}$ & $\begin{array}{c}\text { Amplitude } \\
\text { mean (SD) }\end{array}$ & $\begin{array}{c}\text { Frequency } \\
\text { range }\end{array}$ & $\begin{array}{c}\text { Frequency } \\
\text { mean (SD) }\end{array}$ \\
\hline ACC & 1 to $8 \mathrm{~mA}$ & $4.65(2.10) \mathrm{mA}$ & 50 to $50 \mathrm{~Hz}$ & $50.00(0.00) \mathrm{Hz}$ \\
OFC & 1 to $10 \mathrm{~mA}$ & $4.73(2.82) \mathrm{mA}$ & 2 to $50 \mathrm{~Hz}$ & $40.27(18.46) \mathrm{Hz}$ \\
INS & 2 to $10 \mathrm{~mA}$ & $5.16(2.47) \mathrm{mA}$ & 10 to $50 \mathrm{~Hz}$ & $48.16(9.26) \mathrm{Hz}$
\end{tabular}


Table 2. Demographic information about patient characteristics for electrodes in anterior cingulate, orbitofrontal, and insular cortices.

\begin{tabular}{l|lllllll}
\hline $\begin{array}{l}\text { Subject } \\
\text { ID }\end{array}$ & $\begin{array}{l}\text { Age } \\
\text { (years) }\end{array}$ & Sex & $\begin{array}{l}\text { Dominant } \\
\text { hand }\end{array}$ & $\begin{array}{l}\text { Electrode } \\
\text { type }\end{array}$ & $\begin{array}{l}\text { Stimulated } \\
\text { electrodes } \\
\text { of interest }\end{array}$ & $\begin{array}{l}\text { Stimulated } \\
\text { ROI }\end{array}$ & General effects \\
\hline $\mathbf{1}$ & 57 & F & Right & Subdural & 12 & OFC & Olfactory \\
\hline $\mathbf{2}$ & 38 & M & Right & Subdural & 3 & ACC & Visceral/somatic \\
\hline $\mathbf{3}$ & 50 & M & Left & Depth & 11 & $\begin{array}{l}\text { ACC and } \\
\text { INS }\end{array}$ & Visceral/somatic \\
\hline $\mathbf{4}$ & 47 & M & Right & Depth & 13 & $\begin{array}{l}\text { ACC and } \\
\text { OFC }\end{array}$ & Gustatory; visceral/somatic \\
\hline $\mathbf{5}$ & 41 & M & Right & Depth & 9 & $\begin{array}{l}\text { ACC and } \\
\text { INS }\end{array}$ & Affective without sensory content \\
\hline $\mathbf{6}$ & 48 & F & Right & Subdural & 5 & OFC & Olfactory; visceral/somatic \\
\hline $\mathbf{7}$ & 60 & M & Right & Depth & 10 & OFC & Olfactory and gustatory \\
\hline $\mathbf{8}$ & 65 & F & Right & Subdural & 7 & OFC & $\begin{array}{l}\text { Olfactory and gustatory; } \\
\text { visceral/somatic }\end{array}$ \\
\hline $\mathbf{9}$ & 35 & M & Right & Both & 1 & OFC & Olfactory; visceral/somatic \\
\hline $\mathbf{1 0}$ & 45 & M & Left & Subdural & 7 & ACC and & Olfactory; visceral/somatic \\
\hline $\mathbf{1 1}$ & 25 & F & Right & Depth & 3 & ACC & Visceral/somatic \\
\hline $\mathbf{1 2}$ & 36 & F & Right & Both & 6 & OFC & Olfactory \\
\hline $\mathbf{1 3}$ & 30 & M & Right & Depth & 23 & ACC, OFC, & Olfactory; visceral/somatic; affective \\
& & & & and INS & without sensory content \\
& & & & & & AFC & \\
\hline
\end{tabular}




\begin{tabular}{l|lllllll}
\hline $\begin{array}{l}\text { Subject } \\
\text { ID }\end{array}$ & $\begin{array}{l}\text { Age } \\
\text { (years) }\end{array}$ & Sex & $\begin{array}{l}\text { Dominant } \\
\text { hand }\end{array}$ & $\begin{array}{l}\text { Electrode } \\
\text { type }\end{array}$ & $\begin{array}{l}\text { Stimulated } \\
\text { electrodes } \\
\text { of interest }\end{array}$ & $\begin{array}{l}\text { Stimulated } \\
\text { ROI }\end{array}$ & General effects \\
\hline $\mathbf{1 4}$ & 25 & F & Right & Depth & 1 & ACC & Visceral/somatic \\
\hline $\mathbf{1 5}$ & 47 & F & Right & Depth & 5 & INS & $\begin{array}{l}\text { Olfactory and gustatory; } \\
\text { visceral/somatic }\end{array}$ \\
\hline 16 & 31 & M & Right & Depth & 11 & INS & Gustatory; visceral/somatic \\
\hline $\mathbf{1 7}$ & 19 & F & Right & Depth & 4 & $\begin{array}{l}\text { ACC and } \\
\text { INS }\end{array}$ & Visceral/somatic \\
\hline 18 & 23 & M & Right & Depth & 9 & $\begin{array}{l}\text { ACC and } \\
\text { INS }\end{array}$ & $\begin{array}{l}\text { Olfactory; visceral/somatic; affective } \\
\text { without sensory content }\end{array}$ \\
\hline
\end{tabular}


Table 3. Effects elicited by modulating the parameters of stimulation.

\begin{tabular}{|c|c|c|c|}
\hline $\begin{array}{l}\text { Subject } \\
\text { ID }\end{array}$ & $\begin{array}{l}\text { Electrode Pairing (label } \\
\text { indicates ROI, with REF as } \\
\text { reference electrode not in } \\
\text { ROI) }\end{array}$ & $\begin{array}{l}\text { Modulated } \\
\text { Stimulation } \\
\text { Parameters }\end{array}$ & Affective Subjective Report \\
\hline 1 & OFC 1, OFC 2 & 1 to $3 \mathrm{~mA}$ & "sickening sweet" smell that became stronger \\
\hline 2 & ACC 1, ACC 2 & 4 to $2 \mathrm{~mA}$ & "sexually excited", euphoric sensation that became nothing \\
\hline 2 & ACC 2, ACC 3 & 4 to $6 \mathrm{~mA}$ & "erotic" feeling that became stronger ("whoa!") \\
\hline 2 & ACC 3, REF & 4 to $6 \mathrm{~mA}$ & erection sensation that became a "good" feeling \\
\hline 2 & ACC 3, REF & 6 to $8 \mathrm{~mA}$ & $\begin{array}{l}\text { good feeling that became sensation of someone moving him } \\
\text { from within }\end{array}$ \\
\hline 3 & INS 1, INS 2 & 6 to $8 \mathrm{~mA}$ & $\begin{array}{l}\text { nothing became a nauseous feeling ("almost had a dry } \\
\text { heave") }\end{array}$ \\
\hline 3 & ACC 1, ACC 2 & 4 to $6 \mathrm{~mA}$ & $\begin{array}{l}\text { nothing became an upper respiratory sensation and } \\
\text { foreboding feeling (like "driving into a storm") }\end{array}$ \\
\hline 3 & ACC 2, ACC 3 & 4 to $5 \mathrm{~mA}$ & nothing became sexual arousal \\
\hline 4 & ACC 1, ACC 2 & 3 to $5 \mathrm{~mA}$ & $\begin{array}{l}\text { irritable feeling that became "hot flash" in chest, face, and } \\
\text { neck with feeling of impatience }\end{array}$ \\
\hline 4 & ACC 1, ACC 2 & 5 to $4 \mathrm{~mA}$ & $\begin{array}{l}\text { hot flash that became feeling of needing to fight ("I am } \\
\text { worried that something bad is going to happen to me } \\
\text { physically") }\end{array}$ \\
\hline 4 & OFC 1 , OFC 2 & 10 to $1 \mathrm{~mA}$ & dull "metallic, saline" taste became nothing \\
\hline 4 & OFC 1, OFC 2 & 1 to $3 \mathrm{~mA}$ & nothing became dull saline taste \\
\hline
\end{tabular}




\begin{tabular}{|c|c|c|c|}
\hline $\begin{array}{l}\text { Subject } \\
\text { ID }\end{array}$ & $\begin{array}{l}\text { Electrode Pairing (label } \\
\text { indicates ROI, with REF as } \\
\text { electrode not in ROI) }\end{array}$ & $\begin{array}{l}\text { Modulated } \\
\text { Stimulation } \\
\text { Parameters }\end{array}$ & Affective Subjective Report \\
\hline 4 & OFC 3, OFC 4 & 5 to $7 \mathrm{~mA}$ & $\begin{array}{l}\text { slight anger that became very upset feeling with crying } \\
\text { behavior }\end{array}$ \\
\hline 4 & OFC 3 , OFC 4 & 7 to $5 \mathrm{~mA}$ & anger that became "a little bit negative and angry" \\
\hline 4 & OFC 3, OFC 4 & 5 to $7 \mathrm{~mA}$ & nothing became anger ("mad about something") \\
\hline 5 & INS 1, INS 2 & 8 to $4 \mathrm{~mA}$ & $\begin{array}{l}\text { scared feeling became scared feeling that gradually ramped } \\
\text { up (similar to aura, but not as intense) }\end{array}$ \\
\hline 5 & INS 1, INS 2 & 2 to $4 \mathrm{~mA}$ & nothing became "scared feeling" \\
\hline 5 & ACC 1, ACC 2 & 2 to $4 \mathrm{~mA}$ & $\begin{array}{l}\text { nothing became "general welling up, anticipation" feeling that } \\
\text { was negative }\end{array}$ \\
\hline 5 & ACC 1, ACC 2 & 4 to $2 \mathrm{~mA}$ & negative feeling became nothing \\
\hline 6 & OFC 1, OFC 2 & 4 to $6 \mathrm{~mA}$ & nothing became numbness in left arm \\
\hline 6 & OFC 1 , OFC 2 & 8 to $10 \mathrm{~mA}$ & nothing became dizziness \\
\hline 7 & OFC 1, OFC 2 & 6 to $4 \mathrm{~mA}$ & "candy" taste that became a milder "sniff of fruit" \\
\hline 8 & OFC 1 , OFC 3 & 2 to $4 \mathrm{~mA}$ & $\begin{array}{l}\text { slight smell that became a "broader" and "familiar" smell and } \\
\text { taste that "had a soapy coating to it" }\end{array}$ \\
\hline 8 & OFC 1 , OFC 3 & 50 to $5 \mathrm{~Hz}$ & $\begin{array}{l}\text { smell and taste that became just a smell that was "not as } \\
\text { intense" }\end{array}$ \\
\hline 8 & OFC 1 , OFC 3 & 5 to $2 \mathrm{~Hz}$ & smell and taste that became "mild" smell \\
\hline 8 & REF, OFC 3 & 2 to $50 \mathrm{~Hz}$ & brief smell that became a sharp taste \\
\hline 8 & REF, OFC 3 & 5 to $10 \mathrm{~Hz}$ & $\begin{array}{l}\text { brief smell became immediate smell paired with "rough" } \\
\text { sensation in mouth }\end{array}$ \\
\hline
\end{tabular}




\begin{tabular}{|c|c|c|c|}
\hline $\begin{array}{l}\text { Subject } \\
\text { ID }\end{array}$ & $\begin{array}{l}\text { Electrode Pairing (label } \\
\text { indicates ROI, with REF as } \\
\text { electrode not in ROI) }\end{array}$ & $\begin{array}{l}\text { Modulated } \\
\text { Stimulation } \\
\text { Parameters }\end{array}$ & Affective Subjective Report \\
\hline 8 & REF, OFC 3 & 4 to $8 \mathrm{~mA}$ & $\begin{array}{l}\text { familiar, broad "chemical" taste that became unpleasant } \\
\text { organic taste }\end{array}$ \\
\hline 8 & REF, OFC 3 & 20 to $2 \mathrm{~Hz}$ & unpleasant taste that became nothing \\
\hline 8 & REF, OFC 3 & 2 to $5 \mathrm{~Hz}$ & nothing became brief smell \\
\hline 8 & OFC 2, REF & 8 to $4 \mathrm{~mA}$ & Strong unpleasant smell that became nothing \\
\hline 8 & REF, OFC 4 & 6 to $4 \mathrm{~mA}$ & mild, "soapy" smell that became nothing \\
\hline 8 & REF, OFC 5 & 4 to $6 \mathrm{~mA}$ & $\begin{array}{l}\text { "faint, organic" smell that became "chili pepper" taste that } \\
\text { was neither pleasant nor unpleasant }\end{array}$ \\
\hline 9 & OFC 1, REF & 4 to $8 \mathrm{~mA}$ & $\begin{array}{l}\text { smell and cold sensation in nose ("as if I was in a colder } \\
\text { temperature") that became stronger and "more sensitive" }\end{array}$ \\
\hline 10 & ACC 1, ACC 2 & 5 to $1 \mathrm{~mA}$ & Sudden pain and fear paired with crying that became nothing \\
\hline 10 & ACC 1, ACC 2 & 1 to $2 \mathrm{~mA}$ & nothing that became pain and fear \\
\hline 10 & OFC 1 , OFC 3 & $\begin{array}{l}50 \mathrm{~Hz}, 1 \mathrm{~s} \\
\text { to } 2 \mathrm{~Hz}, 5 \mathrm{~s}\end{array}$ & bad smell (15\%) became less (10\%) bad \\
\hline 10 & OFC 1 , OFC 3 & 2 to $5 \mathrm{~Hz}$ & $\begin{array}{l}\text { "very little smell" that was } 10 \% \text { distasteful became "bad ( } 20 \% \\
\text { distasteful)" }\end{array}$ \\
\hline 10 & OFC 1 , OFC 3 & 5 to $10 \mathrm{~Hz}$ & $\begin{array}{l}\text { bad smell that was } 20 \% \text { distasteful became "distasteful } \\
(40 \%) "\end{array}$ \\
\hline 10 & OFC 1 , OFC 3 & 10 to $20 \mathrm{~Hz}$ & "distasteful (40\%)" smell became "very distasteful (60\%)" \\
\hline
\end{tabular}




\begin{tabular}{|c|c|c|c|}
\hline $\begin{array}{l}\text { Subject } \\
\text { ID }\end{array}$ & $\begin{array}{l}\text { Electrode Pairing (label } \\
\text { indicates ROI, with REF as } \\
\text { electrode not in ROI) }\end{array}$ & $\begin{array}{l}\text { Modulated } \\
\text { Stimulation } \\
\text { Parameters }\end{array}$ & Affective Subjective Report \\
\hline 10 & OFC 1, OFC 2 & $\begin{array}{l}10 \mathrm{~Hz}, 5 \mathrm{~s} \\
\text { to } 20 \mathrm{~Hz}, 1 \\
\mathrm{~s}\end{array}$ & $\begin{array}{l}\text { neither bad nor good smell with intensity } 30 \% \text { went to bad } \\
\text { smell at } 50 \%\end{array}$ \\
\hline 11 & ACC 1, ACC 2 & 4 to $6 \mathrm{~mA}$ & $\begin{array}{l}\text { "roller coaster" sensation that became "scary" feeling that } \\
\text { reaches from right leg to face }\end{array}$ \\
\hline 11 & ACC 1, ACC 2 & 2 to $4 \mathrm{~mA}$ & nothing became "roller coaster feeling" \\
\hline 11 & ACC 2, ACC 3 & 4 to $6 \mathrm{~mA}$ & $\begin{array}{l}\text { "tingling sensation" that became "moving up" sensation } \\
\text { paired with fear, sadness, and crying }\end{array}$ \\
\hline 12 & OFC 1, OFC 2 & $\begin{array}{l}5 \mathrm{~Hz} \text { to } 2 \\
\mathrm{~Hz}\end{array}$ & "slight smell" that became negative \\
\hline 12 & OFC 1 , OFC 2 & $\begin{array}{l}2 \mathrm{~mA}, 50 \\
\mathrm{~Hz} \text { to } 6 \mathrm{~mA} \\
5 \mathrm{~Hz}\end{array}$ & "sharp", negative smell that became "slight smell" \\
\hline 13 & ACC 1, ACC 2 & 6 to $8 \mathrm{~mA}$ & anxiety that became fear \\
\hline 13 & INS 1, INS 2 & 6 to $8 \mathrm{~mA}$ & anxiety that "stopped breath" that became stronger \\
\hline 13 & INS 1, INS 2 & 8 to $6 \mathrm{~mA}$ & strong anxiety that became bodily sensation \\
\hline 13 & INS 2 , OFC 1 & 6 to $8 \mathrm{~mA}$ & $\begin{array}{l}\text { smell in mouth that became diffuse in nasal areas ("opens up } \\
\text { my nasal area") }\end{array}$ \\
\hline 13 & INS 2, OFC 1 & 8 to $10 \mathrm{~mA}$ & broad smell that became nothing \\
\hline 14 & REF, ACC 1 & 2 to $4 \mathrm{~mA}$ & stiffness in bones that became fear and "shaky" sensation \\
\hline 15 & INS 1, INS 2 & 4 to $6 \mathrm{~mA}$ & "weird" smell that became "bad chocolate" taste \\
\hline 15 & INS 1, INS 2 & 6 to $4 \mathrm{~mA}$ & bad chocolate taste that became smell and taste \\
\hline
\end{tabular}




\begin{tabular}{|c|c|c|c|}
\hline $\begin{array}{l}\text { Subject } \\
\text { ID }\end{array}$ & $\begin{array}{l}\text { Electrode Pairing (label } \\
\text { indicates ROI, with REF as } \\
\text { electrode not in ROI) }\end{array}$ & $\begin{array}{l}\text { Modulated } \\
\text { Stimulation } \\
\text { Parameters }\end{array}$ & Affective Subjective Report \\
\hline 15 & INS 1, INS 2 & $\begin{array}{l}10 \mathrm{~mA}, 10 \\
\mathrm{~Hz} \text { to } 4 \mathrm{~mA} \\
20 \mathrm{~Hz}\end{array}$ & nothing became "heart rate increase" \\
\hline 15 & INS 1, INS 2 & 4 to $6 \mathrm{~mA}$ & heart rate increase became a fluttering sensation in chest \\
\hline 15 & INS 1, INS 2 & $\begin{array}{l}6 \mathrm{~mA}, 20 \\
\mathrm{~Hz} \text { to } 4 \mathrm{~mA} \\
50 \mathrm{~Hz}\end{array}$ & chest fluttering sensation that became "bad smell" \\
\hline 16 & INS 1, INS 2 & 6 to $4 \mathrm{~mA}$ & smell and "shaky" sensation that became a "good" taste \\
\hline 16 & INS 1, INS 2 & 4 to $2 \mathrm{~mA}$ & good taste that became nothing \\
\hline 16 & INS 1, INS 2 & 2 to $3 \mathrm{~mA}$ & nothing became taste in throat and nose \\
\hline 16 & INS 3, INS 4 & 6 to $3 \mathrm{~mA}$ & mild taste that became a warm sensation in throat \\
\hline 16 & INS 3 INS 4 & 2 to $6 \mathrm{~mA}$ & nothing became mild taste ("flavor") \\
\hline 17 & ACC 1, ACC 2 & 5 to $2 \mathrm{~mA}$ & $\begin{array}{l}\text { fear and sensation of shock in heart, out of my mouth, and } \\
\text { down my arms that became less intense }\end{array}$ \\
\hline 17 & INS 1, INS 2 & $\begin{array}{l}3.5 \text { to } 2.5 \\
\mathrm{~mA}\end{array}$ & $\begin{array}{l}\text { burning throat sensation and nervous feeling that became } \\
\text { less intense }\end{array}$ \\
\hline 18 & RAIN 5, RAIN 6 & 2 to $4 \mathrm{~mA}$ & slight pleasant smell of "rain" that became stronger \\
\hline 18 & RAIN 4, RAIN 5 & 4 to $6 \mathrm{~mA}$ & $\begin{array}{l}\text { nothing became sensation of increased heart rate "like when } \\
\text { you finish running" }\end{array}$ \\
\hline 18 & $\mathrm{RACl} 2, \mathrm{RACl} 3$ & 4 to $6 \mathrm{~mA}$ & nothing became "lightheaded" sensation \\
\hline 18 & $\mathrm{RACl} 2, \mathrm{RACl} 3$ & 6 to $8 \mathrm{~mA}$ & "lightheaded" sensation that became stronger \\
\hline
\end{tabular}




\begin{tabular}{|c|c|c|c|}
\hline $\begin{array}{l}\text { Subject } \\
\text { ID }\end{array}$ & $\begin{array}{l}\text { Electrode Pairing (label } \\
\text { indicates ROI, with REF as } \\
\text { electrode not in ROI) }\end{array}$ & $\begin{array}{l}\text { Modulated } \\
\text { Stimulation } \\
\text { Parameters }\end{array}$ & Affective Subjective Report \\
\hline 18 & $\mathrm{RMCl} 1, \mathrm{RMCl} 2$ & 4 to $6 \mathrm{~mA}$ & $\begin{array}{l}\text { nothing became anxious feeling "like something bad is going } \\
\text { to happen" }\end{array}$ \\
\hline 18 & $\mathrm{RMCl} 1, \mathrm{RMCl} 2$ & 6 to $8 \mathrm{~mA}$ & anxious feeling that became fear "but hopeful in a weird way" \\
\hline 18 & RMIN 3, RMIN 4 & 4 to $6 \mathrm{~mA}$ & nothing became sensation of "falling backwards" \\
\hline
\end{tabular}



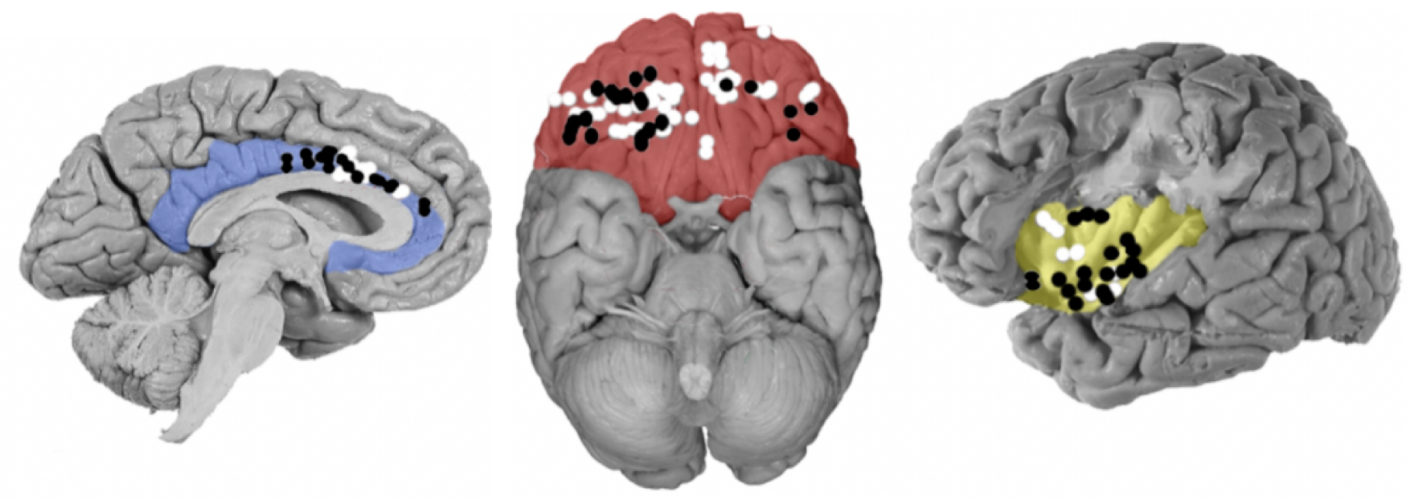

"Hot spot" electrodes where affective subjective experiences were elicited by iES

Electrodes that did not elicit affective subjective experiences

Figure 1. Elicitation of affective subjective experiences with intracranial electrical stimulation (iES). The anterior cingulate gyrus (ACC; in blue), orbitofrontal cortex (OFC; in red), and insular cortex (INS; in yellow) were chosen as the ROIs because of their known involvement in affective processing. Notably, all cingulate electrodes were in the anterior half of the cingulate gyrus (ACC). Across all patients, 140 electrodes in the ACC, OFC, and INS were stimulated at varying stimulation parameters (i.e., amplitude and/or frequency). In $46 \%$ of these electrodes, affective subjective experiences were elicited by iES. We plotted the anatomical location of all electrodes in standardized anatomical space. The location of each electrode may not be precisely in the shown locations. It is worth noting that, though there are more hot spot electrodes in the right compared to the left OFC, there were no hemispheric differences in the relative frequencies of hot spot electrodes in OFC. In addition, there were no hemispheric differences in the relative frequencies of hot spot electrodes in ACC or in INS. Thus, for ACC and INS, we projected all electrodes onto the left hemisphere. 
A)
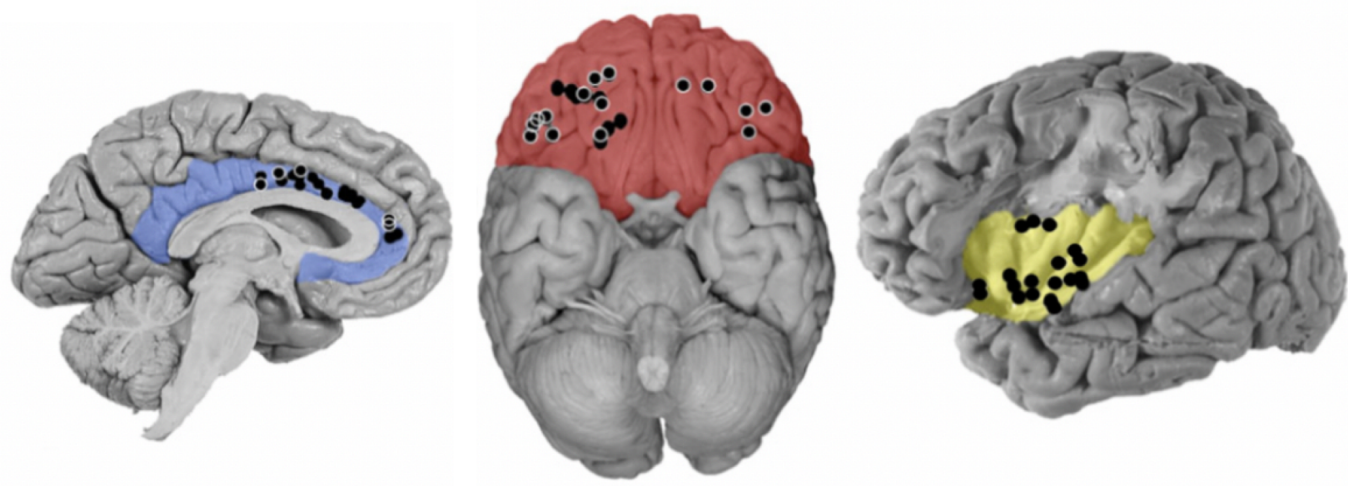

B)

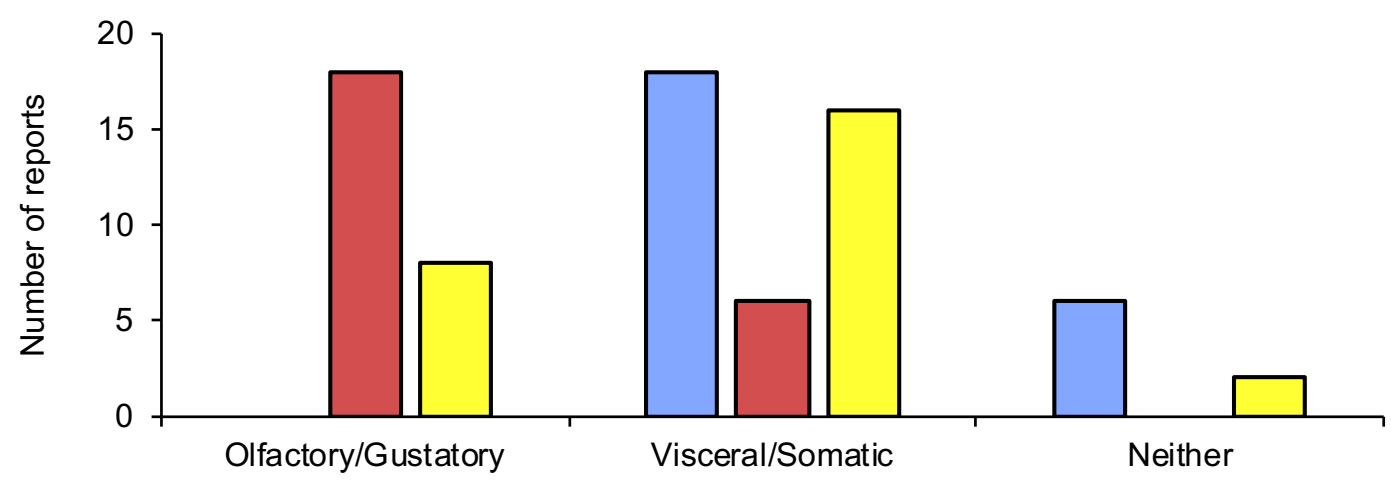

C)

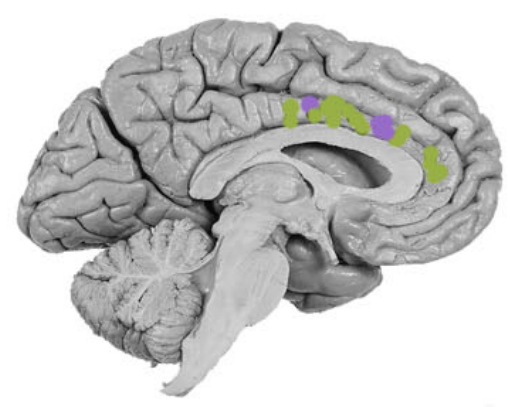

Visceral/Somatic
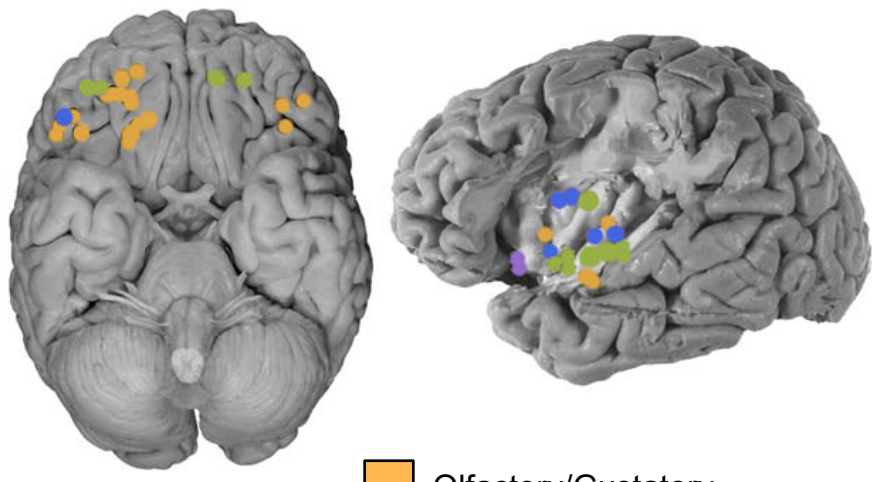

Neither (affective without sensory content)

Visceral/Somatic

Figure 2. Regionally specific effects of iES. A) We plotted the anatomical location of our 65 "hot spot" electrodes on standardized anatomical space to summarize the anatomical location of changes in subjective affective experience (white outline indicates a subdural electrode). Each electrode exhibited a change in intensity when stimulation magnitude was modulated. Given that there were no hemispheric differences for ACC or for INS, we projected all electrodes in these ROIs onto the left hemisphere. B) Different profiles of affective experience were elicited by stimulation to each anatomical ROI. C) Different modalities of affective experiences were elicited by stimulation to specific regions within each ROI. 

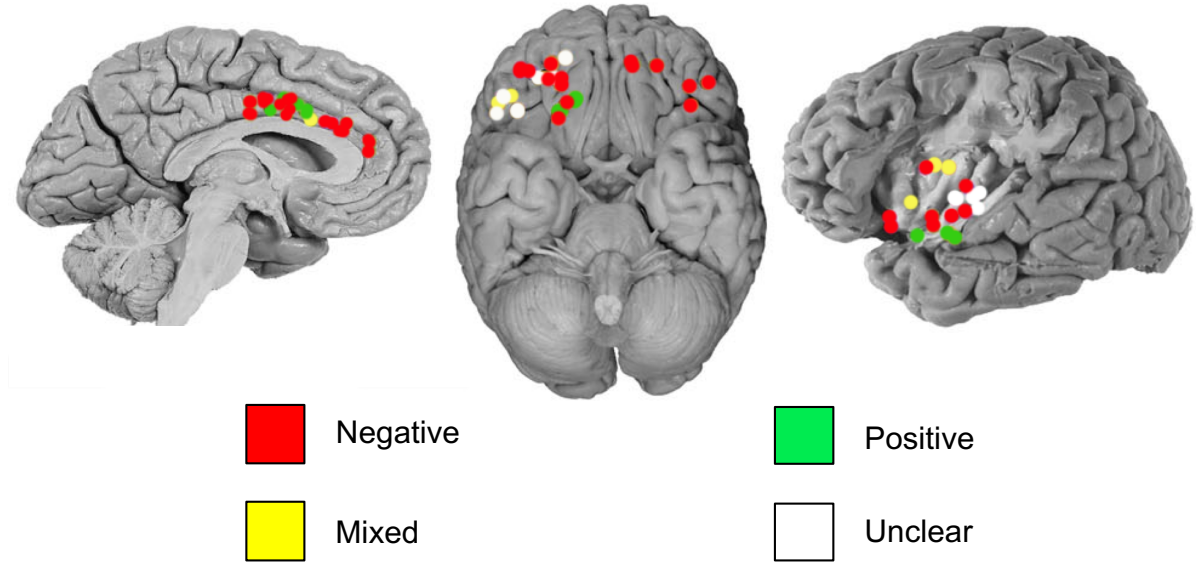

Figure 3. Valence-specific effects of iES. A) We categorized each subjective experience based on valence and found that distinctly valenced affective experiences were elicited by stimulation to specific regions within each ROI. 
Supplemental Material Table 1. Detailed summary of Subject 15's reported subjective experience.

\begin{tabular}{|c|c|c|}
\hline $\begin{array}{l}\text { Location } \\
\text { (relative to } \\
\text { INS 1) }\end{array}$ & Electrode & $\begin{array}{l}\text { Stimulation Parameters } \rightarrow \text { Affective Subjective } \\
\text { Report }\end{array}$ \\
\hline INS 1 & INS 1 & $\begin{array}{ll}\text { - } & 50 \mathrm{~Hz}, 4 \mathrm{~mA}, 1 \mathrm{~s} \rightarrow \text { weird smell } \\
\text { - } & 50 \mathrm{~Hz}, 6 \mathrm{~mA}, 1 \mathrm{~s} \rightarrow \text { chocolate taste } \\
\text { - } & 50 \mathrm{~Hz}, 6 \mathrm{~mA}, 2 \mathrm{~s} \rightarrow \text { bad chocolate taste } \\
\text { - } & 50 \mathrm{~Hz}, 4 \mathrm{~mA}, 1 \mathrm{~s} \rightarrow \text { both smell and taste } \\
\text { - } & 5 \mathrm{~Hz}, 4 \mathrm{~mA}, 1 \mathrm{~s} \rightarrow \text { none } \\
\text { - } & 5 \mathrm{~Hz}, 10 \mathrm{~mA}, 1 \mathrm{~s} \rightarrow \text { none } \\
\text { - } & 10 \mathrm{~Hz}, 10 \mathrm{~mA}, 1 \mathrm{~s}, \rightarrow \text { none } \\
\text { - } & 20 \mathrm{~Hz}, 4 \mathrm{~mA}, 1 \mathrm{~s} \rightarrow \text { something happened, but } \\
& \text { too fast to describe } \\
\text { - } & 20 \mathrm{~Hz}, 6 \mathrm{~mA}, 1 \mathrm{~s} \rightarrow \text { chest fluttering sensation } \\
\text { - } & 50 \mathrm{~Hz}, 4 \mathrm{~mA}, 1 \mathrm{~s} \rightarrow \text { bad smell again }\end{array}$ \\
\hline $5 \mathrm{~mm}$ ventral & INS 2 & $\begin{array}{l}\text { - } 50 \mathrm{~Hz}, 8 \mathrm{~mA}, 1 \mathrm{~s} \rightarrow \text { rising nausea in the } \\
\text { stomach } \\
\text { - } 50 \mathrm{~Hz}, 10 \mathrm{~mA}, 1 \mathrm{~s} \rightarrow \text { blurry vision }\end{array}$ \\
\hline $10 \mathrm{~mm}$ ventral & INS 3 & $\begin{array}{l}50 \mathrm{~Hz}, 8 \mathrm{~mA}, 1 \mathrm{~s} \rightarrow \text { slight chilly feeling over the } \\
\text { body }\end{array}$ \\
\hline $15 \mathrm{~mm}$ ventral & INS 4 & - $50 \mathrm{~Hz}, 8 \mathrm{~mA}, 1 \mathrm{~s} \rightarrow$ none \\
\hline
\end{tabular}


Supplemental Material Table 2. Specific effects elicited by modulating the frequency of stimulation.

\begin{tabular}{|c|c|c|c|c|c|c|}
\hline $\begin{array}{l}\text { Subject } \\
\text { ID }\end{array}$ & $\begin{array}{l}\text { Electrode } \\
\text { Pairing }\end{array}$ & $\begin{array}{l}\text { Stimulation } \\
\text { Parameters }\end{array}$ & $\begin{array}{l}\text { Charge per pulse } \\
\text { (pulse width } \times \\
\text { current) }\end{array}$ & $\begin{array}{l}\text { Charge per trial } \\
\text { (pulse width } \times \\
\text { current } \times \text { duration } \\
\times \text { frequency) }\end{array}$ & $\begin{array}{l}\text { Affective } \\
\text { Subjective Report }\end{array}$ & $\begin{array}{l}\text { Reports } \\
\text { during } \\
\text { sham/ } \\
\text { Total } \\
\text { sham }\end{array}$ \\
\hline 8 & $\begin{array}{l}\text { OFC 1, } \\
\text { OFC } 3\end{array}$ & $\begin{array}{l}50 \text { to } 5 \mathrm{~Hz} \text { (both } 4 \\
\mathrm{~mA}, 1 \mathrm{~s})\end{array}$ & 0.8 to $0.8 \mu \mathrm{C}$ & 40 to $4 \mu \mathrm{C}$ & $\begin{array}{l}\text { smell and taste that } \\
\text { became just a smell } \\
\text { that was "not as } \\
\text { intense" }\end{array}$ & $0 / 0$ \\
\hline 8 & $\begin{array}{l}\text { OFC 1, } \\
\text { OFC } 3\end{array}$ & $\begin{array}{l}5 \text { to } 2 \mathrm{~Hz} \text { (both } 4 \\
\mathrm{~mA}, 1 \mathrm{~s})\end{array}$ & 0.8 to $0.8 \mu \mathrm{C}$ & 4 to $1.6 \mu \mathrm{C}$ & $\begin{array}{l}\text { smell and taste that } \\
\text { became "mild" smell }\end{array}$ & $0 / 0$ \\
\hline 8 & $\begin{array}{l}\text { REF, OFC } \\
3\end{array}$ & $\begin{array}{l}2 \text { to } 50 \mathrm{~Hz} \text { (both } 4 \\
\mathrm{~mA}, 1 \mathrm{~s} \text { ) }\end{array}$ & 0.8 to $0.8 \mu \mathrm{C}$ & 1.6 to $40 \mu \mathrm{C}$ & $\begin{array}{l}\text { brief smell that } \\
\text { became a sharp } \\
\text { taste }\end{array}$ & $0 / 2$ \\
\hline 8 & $\begin{array}{l}\text { REF, OFC } \\
3\end{array}$ & $\begin{array}{l}5 \text { to } 10 \mathrm{~Hz} \text { (both } 8 \\
\mathrm{~mA}, 1 \mathrm{~s})\end{array}$ & 1.6 to $1.6 \mu \mathrm{C}$ & 8 to $16 \mu C$ & $\begin{array}{l}\text { brief smell became } \\
\text { immediate smell } \\
\text { paired with "rough" } \\
\text { sensation in mouth }\end{array}$ & $0 / 0$ \\
\hline 8 & $\begin{array}{l}\text { REF, OFC } \\
3\end{array}$ & $\begin{array}{l}20 \text { to } 2 \mathrm{~Hz} \text { (both } 8 \\
\mathrm{~mA}, 1 \mathrm{~s} \text { ) }\end{array}$ & 1.6 to $1.6 \mu \mathrm{C}$ & 32 to $3.2 \mu \mathrm{C}$ & $\begin{array}{l}\text { unpleasant taste } \\
\text { that became nothing }\end{array}$ & $0 / 0$ \\
\hline 8 & $\begin{array}{l}\text { REF, OFC } \\
3\end{array}$ & $\begin{array}{l}2 \text { to } 5 \mathrm{~Hz}(8 \mathrm{~mA}, 1 \\
\mathrm{s})\end{array}$ & 1.6 to $1.6 \mu \mathrm{C}$ & 3.2 to $8 \mu \mathrm{C}$ & $\begin{array}{l}\text { nothing became } \\
\text { brief smell }\end{array}$ & $0 / 0$ \\
\hline 10 & $\begin{array}{l}\text { OFC } 1 \\
\text { OFC } 3\end{array}$ & $\begin{array}{l}50 \mathrm{~Hz}, 1 \mathrm{~s} \text { to } 2 \\
\mathrm{~Hz}, 5 \mathrm{~s} \text { (both } 5 \\
\mathrm{~mA} \text { ) }\end{array}$ & 1 to $1 \mu \mathrm{C}$ & 100 to $50 \mu \mathrm{C}$ & $\begin{array}{l}\text { bad smell that was } \\
15 \% \text { bad became } \\
10 \% \text { bad }\end{array}$ & \\
\hline 10 & $\begin{array}{l}\text { OFC 1, } \\
\text { OFC } 3\end{array}$ & $\begin{array}{l}2 \text { to } 5 \mathrm{~Hz} \text { (both } 5 \\
\mathrm{~mA}, 5 \mathrm{secs})\end{array}$ & 1 to $1 \mu \mathrm{C}$ & 50 to $125 \mu \mathrm{C}$ & $\begin{array}{l}\text { "very little smell" that } \\
\text { was } 10 \% \text { distasteful } \\
\text { that became "bad } \\
\text { ( } 20 \% \text { distasteful)" }\end{array}$ & $0 / 1$ \\
\hline
\end{tabular}




\begin{tabular}{|c|c|c|c|c|c|c|}
\hline $\begin{array}{l}\text { Subject } \\
\text { ID }\end{array}$ & $\begin{array}{l}\text { Electrode } \\
\text { Pairing }\end{array}$ & $\begin{array}{l}\text { Stimulation } \\
\text { Parameters }\end{array}$ & $\begin{array}{l}\text { Charge per pulse } \\
\text { (pulse width } \times \\
\text { current) }\end{array}$ & $\begin{array}{l}\text { Charge per trial } \\
\text { (pulse width } \times \\
\text { current } \times \text { duration } \\
\times \text { frequency) }\end{array}$ & $\begin{array}{l}\text { Affective } \\
\text { Subjective Report }\end{array}$ & $\begin{array}{l}\text { Reports } \\
\text { during } \\
\text { sham } / \\
\text { Total } \\
\text { sham }\end{array}$ \\
\hline 10 & $\begin{array}{l}\text { OFC 1, } \\
\text { OFC } 3\end{array}$ & $\begin{array}{l}5 \text { to } 10 \mathrm{~Hz} \text { (both } 5 \\
\mathrm{~mA}, 5 \mathrm{~s} \text { ) }\end{array}$ & 1 to $1 \mu \mathrm{C}$ & 125 to $250 \mu \mathrm{C}$ & $\begin{array}{l}\text { bad smell that was } \\
20 \% \text { distasteful that } \\
\text { became "distasteful } \\
(40 \%) "\end{array}$ & $0 / 1$ \\
\hline 10 & $\begin{array}{l}\text { OFC 1, } \\
\text { OFC } 3\end{array}$ & $\begin{array}{l}10 \mathrm{~Hz}, 5 \mathrm{~s} \text { to } 20 \\
\mathrm{~Hz}, 3 \mathrm{~s} \text { (both } 5 \\
\mathrm{~mA} \text { ) }\end{array}$ & 1 to $1 \mu \mathrm{C}$ & 50 to $60 \mu \mathrm{C}$ & $\begin{array}{l}\text { "distasteful (40\%)" } \\
\text { smell that became } \\
\text { "very distasteful } \\
(60 \%) "\end{array}$ & $1 / 1$ \\
\hline 10 & $\begin{array}{l}\text { OFC 1, } \\
\text { OFC } 2\end{array}$ & $\begin{array}{l}10 \mathrm{~Hz}, 5 \mathrm{~s} \text { to } 20 \\
\mathrm{~Hz}, 1 \mathrm{~s} \text { (both } 5 \\
\mathrm{~mA} \text { ) }\end{array}$ & 1 to $1 \mu \mathrm{C}$ & 50 to $20 \mu \mathrm{C}$ & $\begin{array}{l}\text { neither bad nor } \\
\text { good smell with } \\
\text { intensity } 30 \% \text { went } \\
\text { to bad smell at } 50 \%\end{array}$ & $0 / 0$ \\
\hline 12 & $\begin{array}{l}\text { OFC 1, } \\
\text { OFC } 2\end{array}$ & $\begin{array}{l}5 \text { to } 2 \mathrm{~Hz} \text { (both } 6 \\
\mathrm{~mA}, 1 \mathrm{~s} \text { ) }\end{array}$ & 1.2 to $1.2 \mu \mathrm{C}$ & 36 to $14.4 \mu \mathrm{C}$ & $\begin{array}{l}\text { "slight smell" that } \\
\text { became negative }\end{array}$ & $0 / 0$ \\
\hline 12 & $\begin{array}{l}\text { OFC 1, } \\
\text { OFC } 2\end{array}$ & $\begin{array}{l}2 \mathrm{~mA}, 50 \mathrm{~Hz} \text { to } 6 \\
\mathrm{~mA}, 5 \mathrm{~Hz} \text { (both } 1 \\
\mathrm{~s} \text { ) }\end{array}$ & 0.4 to $1.2 \mu \mathrm{C}$ & 20 to $6 \mu \mathrm{C}$ & $\begin{array}{l}\text { "sharp", negative } \\
\text { smell that became } \\
\text { "slight smell" }\end{array}$ & $0 / 0$ \\
\hline 15 & $\begin{array}{l}\text { INS 1, } \\
\text { INS } 2\end{array}$ & $\begin{array}{l}6 \mathrm{~mA}, 20 \mathrm{~Hz} \text { to } 4 \\
\mathrm{~mA}, 50 \mathrm{~Hz} \text { (both } 1 \\
\mathrm{~s} \text { ) }\end{array}$ & 1.2 to $0.8 \mu \mathrm{C}$ & 24 to $40 \mu \mathrm{C}$ & $\begin{array}{l}\text { chest fluttering } \\
\text { sensation that } \\
\text { became "bad smell" }\end{array}$ & $0 / 0$ \\
\hline 15 & $\begin{array}{l}\text { INS 1, } \\
\text { INS } 2\end{array}$ & $\begin{array}{l}10 \mathrm{~mA}, 10 \mathrm{~Hz} \text { to } 4 \\
\mathrm{~mA}, 20 \mathrm{~Hz} \text { (both } 1 \\
\mathrm{~s} \text { ) }\end{array}$ & 2 to $0.8 \mu \mathrm{C}$ & 20 to $16 \mu \mathrm{C}$ & $\begin{array}{l}\text { nothing became } \\
\text { "heart rate increase" }\end{array}$ & $0 / 2$ \\
\hline
\end{tabular}




\section{References}

Achterberg, M., van Duijvenvoorde, A. C., Bakermans-Kranenburg, M. J., \& Crone, E. A. (2016). Control your anger! The neural basis of aggression regulation in response to negative social feedback. Social cognitive and affective neuroscience, 11(5), 712-720.

Adolphs, R., Damasio, H., Tranel, D., Cooper, G., \& Damasio, A. R. (2000). A role for somatosensory cortices in the visual recognition of emotion as revealed by threedimensional lesion mapping. J Neurosci, 20(7), 2683-2690.

Alhourani, A., McDowell, M. M., Randazzo, M. J., Wozny, T. A., Kondylis, E. D., Lipski, W. J., . . . Richardson, R. M. (2015). Network effects of deep brain stimulation. Journal of neurophysiology, 114(4), 2105-2117.

Bar, M., Neta, M., \& Linz, H. (2006). Very first impressions. Emotion, 6(2), 269.

Barbas, H., Saha, S., Rempel-Clower, N., \& Ghashghaei, T. (2003). Serial pathways from primate prefrontal cortex to autonomic areas may influence emotional expression. $B M C$ neuroscience, 4(1), 25.

Baumeister, R. F., Vohs, K. D., DeWall, N. C., \& Zhang, L. (2007). How emotion shapes behavior: Feedback, anticipation, and reflection, rather than direct causation. Personality and Social Psychology Review, 11(2), 167-203.

Bosking, W. H., Sun, P., Ozker, M., Pei, X., Foster, B. L., Beauchamp, M. S., \& Yoshor, D. (2017). Saturation in phosphene size with increasing current levels delivered to human visual cortex. Journal of Neuroscience, 37(30), 7188-7197.

Bremner, J. D., Vythilingam, M., Vermetten, E., Nazeer, A., Adil, J., Khan, S., . . Charney, D. S. (2002). Reduced volume of orbitofrontal cortex in major depression. Biological psychiatry, 51(4), 273-279.

Buhle, J. T., Silvers, J. A., Wager, T. D., Lopez, R., Onyemekwu, C., Kober, H., . . Ochsner, K. N. (2014). Cognitive reappraisal of emotion: a meta-analysis of human neuroimaging studies. Cereb Cortex, 24(11), 2981-2990. doi:10.1093/cercor/bht154

Buzsáki, G., Anastassiou, C. A., \& Koch, C. (2012). The origin of extracellular fields and currents-EEG, ECoG, LFP and spikes. Nature Reviews Neuroscience, 13(6), 407.

Caruana, F., Gerbella, M., Avanzini, P., Gozzo, F., Pelliccia, V., Mai, R., . . . Lo Russo, G. (2018). Motor and emotional behaviours elicited by electrical stimulation of the human cingulate cortex. Brain, 141(10), 3035-3051.

Colibazzi, T., Posner, J., Wang, Z., Gorman, D., Gerber, A., Yu, S., . . Russell, J. A. (2010). Neural systems subserving valence and arousal during the experience of induced emotions. Emotion, 10(3), 377.

Craig, A. D. (2004). Human feelings: why are some more aware than others? Trends in cognitive sciences, 8(6), 239-241.

Craig, A. D. (2009). How do you feel--now? The anterior insula and human awareness. Nature Reviews Neuroscience, 10(1).

Critchley, H. D., \& Garfinkel, S. N. (2017). Interoception and emotion. Current Opinion in Psychology, 17, 7-14.

Damasio, A. (2003). Mental self: The person within. Nature, 423(6937), 227. 
Davidson, R. J., Lewis, D. A., Alloy, L. B., Amaral, D. G., Bush, G., Cohen, J. D., . . Peterson, B. S. (2002). Neural and behavioral substrates of mood and mood regulation. Biol Psychiatry, 52(6), 478-502.

Devinsky, O., Morrell, M. J., \& Vogt, B. A. (1995). Contributions of anterior cingulate cortex to behaviour. Brain, 118(1), 279-306.

Dixon, M. L., Thiruchselvam, R., Todd, R., \& Christoff, K. (2017). Emotion and the prefrontal cortex: An integrative review. Psychological bulletin, 143(10), 1033-1081.

Eisenberger, N. I., Jarcho, J. M., Lieberman, M. D., \& Naliboff, B. D. (2006). An experimental study of shared sensitivity to physical pain and social rejection. Pain, 126(1-3), 132-138.

Eisenberger, N. I., \& Lieberman, M. D. (2004). Why rejection hurts: a common neural alarm system for physical and social pain. Trends in cognitive sciences, 8(7), 294-300.

Etkin, A., \& Wager, T. D. (2007). Functional neuroimaging of anxiety: a meta-analysis of emotional processing in PTSD, social anxiety disorder, and specific phobia. American Journal of Psychiatry, 164(10), 1476-1488.

Famm, K., Litt, B., Tracey, K. J., Boyden, E. S., \& Slaoui, M. (2013). Drug discovery: a jump-start for electroceuticals. Nature, 496(7444), 159.

Feindel, W., \& Penfield, W. (1954). Localization of discharge in temporal lobe automatism. AMA Archives of Neurology \& Psychiatry, 72(5), 605-630.

Fins, J. J., Kubu, C. S., Mayberg, H. S., Merkel, R., Nuttin, B., \& Schlaepfer, T. E. (2017). Being open minded about neuromodulation trials: Finding success in our "failures". In: Elsevier.

Foster, B. L., \& Parvizi, J. (2017). Direct cortical stimulation of human posteromedial cortex. Neurology, 88(7), 685-691. doi:10.1212/WNL.0000000000003607

Fox, K. C., Yih, J., Raccah, O., Pendekanti, S. L., Limbach, L. E., Maydan, D. D., \& Parvizi, J. (2018). Changes in subjective experience elicited by direct stimulation of the human orbitofrontal cortex. Neurology, 10.1212/WNL. 0000000000006358.

Fredrickson, B. L., \& Branigan, C. (2005). Positive emotions broaden the scope of attention and thought-action repertoires. Cognition \& emotion, 19(3), 313-332.

Fried, I., Wilson, C. L., MacDonald, K. A., \& Behnke, E. J. (1998). Electric current stimulates laughter. Nature, 391(6668), 650.

Gallo, S., Paracampo, R., Müller-Pinzler, L., Severo, M. C., Blömer, L., Fernandes-Henriques, C., . . Suttrup, J. (2018). The causal role of the somatosensory cortex in prosocial behaviour. elife, 7, e32740.

Garfinkel, S. N., Seth, A. K., Barrett, A. B., Suzuki, K., \& Critchley, H. D. (2015). Knowing your own heart: distinguishing interoceptive accuracy from interoceptive awareness. Biological psychology, 104, 65-74.

Georgiadis, J., \& Kringelbach, M. L. (2012). The human sexual response cycle: brain imaging evidence linking sex to other pleasures. Progress in neurobiology, 98(1), 49-81.

Golkar, A., Lonsdorf, T. B., Olsson, A., Lindstrom, K. M., Berrebi, J., Fransson, P., . . Öhman, A. (2012). Distinct contributions of the dorsolateral prefrontal and orbitofrontal cortex during emotion regulation. PLoS One, 7(11), e48107.

Gottfried, J. A., \& Zald, D. H. (2005). On the scent of human olfactory orbitofrontal cortex: meta-analysis and comparison to non-human primates. Brain Research Reviews, 50(2), 287-304. 
Guillory, S. A., \& Bujarski, K. A. (2014). Exploring emotions using invasive methods: review of 60 years of human intracranial electrophysiology. Social cognitive and affective neuroscience, 9(12), 1880-1889.

Halgren, E., Walter, R. D., Cherlow, D. G., \& Crandall, P. H. (1978). Mental phenomena evoked by electrical stimulation of the human hippocampal formation and amygdala. Brain, 101(1), 83-115.

Harmon-Jones, E., Gable, P. A., \& Price, T. F. (2012). The influence of affective states varying in motivational intensity on cognitive scope. Front Integr Neurosci, 6, 73. doi:10.3389/fnint.2012.00073

Inman, C. S., Bijanki, K. R., Bass, D. I., Gross, R. E., Hamann, S., \& Willie, J. T. (2018). Human amygdala stimulation effects on emotion physiology and emotional experience. Neuropsychologia.

Izard, C. E. (2009). Emotion theory and research: Highlights, unanswered questions, and emerging issues. Annual review of psychology, 60, 1-25.

Izard, C. E. (2010). The many meanings/aspects of emotion: Definitions, functions, activation, and regulation. Emotion Review, 2(4), 363-370.

Jabbi, M., Swart, M., \& Keysers, C. (2007). Empathy for positive and negative emotions in the gustatory cortex. Neuroimage, 34(4), 1744-1753. doi:https://doi.org/10.1016/j.neuroimage.2006.10.032

Koch, C., Massimini, M., Boly, M., \& Tononi, G. (2016). Neural correlates of consciousness: progress and problems. Nature Reviews Neuroscience, 17(5), 307.

Krause, B., \& Cohen Kadosh, R. (2014). Not all brains are created equal: the relevance of individual differences in responsiveness to transcranial electrical stimulation. Frontiers in systems neuroscience, 8, 25.

Kringelbach, M. L. (2005). The human orbitofrontal cortex: linking reward to hedonic experience. Nature Reviews Neuroscience, 6(9), 691.

Lamm, C., Batson, C. D., \& Decety, J. (2007). The neural substrate of human empathy: effects of perspective-taking and cognitive appraisal. Journal of cognitive neuroscience, 19(1), 4258.

Lamm, C., \& Singer, T. (2010). The role of anterior insular cortex in social emotions. Brain Structure and Function, 214(5-6), 579-591.

Lewis, P. A., Critchley, H., Rotshtein, P., \& Dolan, R. (2006). Neural correlates of processing valence and arousal in affective words. Cerebral cortex, 17(3), 742-748.

Lieberman, M. D., \& Eisenberger, N. I. (2015). The dorsal anterior cingulate cortex is selective for pain: Results from large-scale reverse inference. Proceedings of the National Academy of Sciences, 112(49), 15250-15255.

Lindquist, K. A., Satpute, A. B., Wager, T. D., Weber, J., \& Barrett, L. F. (2015). The brain basis of positive and negative affect: evidence from a meta-analysis of the human neuroimaging literature. Cerebral cortex, 26(5), 1910-1922.

Lindquist, K. A., Wager, T. D., Kober, H., Bliss-Moreau, E., \& Barrett, L. F. (2012). The brain basis of emotion: a meta-analytic review. Behavioral and brain sciences, 35(3), 121-143.

Mangina, C. A., \& Beuzeron-Mangina, J. H. (1996). Direct electrical stimulation of specific human brain structures and bilateral electrodermal activity. International Journal of Psychophysiology, 22(1-2), 1-8. 
Mauss, I. B., Levenson, R. W., McCarter, L., Wilhelm, F. H., \& Gross, J. J. (2005). The tie that binds? Coherence among emotion experience, behavior, and physiology. Emotion, 5(2), 175.

Mayberg, H. S., Brannan, S. K., Mahurin, R. K., Jerabek, P. A., Brickman, J. S., Tekell, J. L., . . . Martin, C. C. (1997). Cingulate function in depression: a potential predictor of treatment response. Neuroreport, 8(4), 1057-1061.

Mayberg, H. S., Lozano, A. M., Voon, V., McNeely, H. E., Seminowicz, D., Hamani, C., .. . Kennedy, S. H. (2005). Deep brain stimulation for treatment-resistant depression. Neuron, 45(5), 651-660.

Mayberg, H. S., Riva-Posse, P., \& Crowell, A. L. (2016). Deep brain stimulation for depression: keeping an eye on a moving target. JAMA Psychiatry, 73(5), 439-440.

Morishita, T., Fayad, S. M., Higuchi, M.-a., Nestor, K. A., \& Foote, K. D. (2014). Deep brain stimulation for treatment-resistant depression: systematic review of clinical outcomes. Neurotherapeutics, 11(3), 475-484.

Mulak, A., Kahane, P., Hoffmann, D., Minotti, L., \& Bonaz, B. (2008). Brain mapping of digestive sensations elicited by cortical electrical stimulations. Neurogastroenterology \& Motility, 20(6), 588-596.

Mullan, S., \& Penfield, W. (1959). Illusions of comparative interpretation and emotion: production by epileptic discharge and by electrical stimulation in the temporal cortex. AMA Archives of Neurology \& Psychiatry, 81(3), 269-284.

Mulligan, K., \& Scherer, K. R. (2012). Toward a Working Definition of Emotion. Emotion Review, 4(4), 345-357. doi:10.1177/1754073912445818

Ochsner, K. N., \& Gross, J. J. (2005). The cognitive control of emotion. Trends Cogn Sci, 9(5), 242-249. doi:10.1016/j.tics.2005.03.010

Oppenheimer, S. M., Gelb, A., Girvin, J. P., \& Hachinski, V. C. (1992). Cardiovascular effects of human insular cortex stimulation. Neurology, 42(9), 1727-1727.

Ortigue, S., Bianchi-Demicheli, F., Patel, N., Frum, C., \& Lewis, J. W. (2010). Neuroimaging of love: $\mathrm{fMRI}$ meta-analysis evidence toward new perspectives in sexual medicine. The journal of sexual medicine, 7(11), 3541-3552.

Ostrowsky, K., Isnard, J., Ryvlin, P., Guénot, M., Fischer, C., \& Mauguière, F. (2000). Functional mapping of the insular cortex: clinical implication in temporal lobe epilepsy. Epilepsia, 41(6), 681-686.

Panksepp, J. (2003). Damasio's error? Consciousness and Emotion, 4(1), 111-134.

Parvizi, J. (2009). Corticocentric myopia: old bias in new cognitive sciences. Trends in cognitive sciences, 13(8), 354-359.

Parvizi, J., \& Kastner, S. (2018). Promises and limitations of human intracranial electroencephalography. Nature neuroscience, 1.

Parvizi, J., Rangarajan, V., Shirer, W. R., Desai, N., \& Greicius, M. D. (2013). The will to persevere induced by electrical stimulation of the human cingulate gyrus. Neuron, 80(6), 13591367.

Paulus, M. P., \& Stein, M. B. (2006). An insular view of anxiety. Biological psychiatry, 60(4), 383387.

Phelps, E. A., Ling, S., \& Carrasco, M. (2006). Emotion facilitates perception and potentiates the perceptual benefits of attention. Psychological science, 17(4), 292-299. 
Pool, J. L., \& Ransohoff, J. (1949). Autonomic effects on stimulating rostral portion of cingulate gyri in man. Journal of neurophysiology, 12(6), 385-392.

Pugnaghi, M., Meletti, S., Castana, L., Francione, S., Nobili, L., Mai, R., \& Tassi, L. (2011). Features of somatosensory manifestations induced by intracranial electrical stimulations of the human insula. Clinical Neurophysiology, 122(10), 2049-2058.

Reuter, M., Schmansky, N. J., Rosas, H. D., \& Fischl, B. (2012). Within-subject template estimation for unbiased longitudinal image analysis. Neuroimage, 61(4), 1402-1418.

Rolls, E. T. (2000). The Orbitofrontal Cortex and Reward. Cerebral cortex, 10(3), 284-294. doi:10.1093/cercor/10.3.284

Roy, H. A., Green, A. L., \& Aziz, T. Z. (2018). State of the art: novel applications for deep brain stimulation. Neuromodulation: Technology at the Neural Interface, 21(2), 126-134.

Royet, J.-P., Plailly, J., Delon-Martin, C., Kareken, D. A., \& Segebarth, C. (2003). fMRI of emotional responses to odors:: influence of hedonic valence and judgment, handedness, and gender. Neuroimage, 20(2), 713-728. doi:https://doi.org/10.1016/S10538119(03)00388-4

Russell, J. A. (1980). A circumplex model of affect. Journal of personality and social psychology, 39(6), 1161.

Selimbeyoglu, A., \& Parvizi, J. (2010). Electrical stimulation of the human brain: perceptual and behavioral phenomena reported in the old and new literature. Frontiers in human neuroscience, 4, 46.

Simmons, A. N., Arce, E., Lovero, K. L., Stein, M. B., \& Paulus, M. P. (2009). Subchronic SSRI administration reduces insula response during affective anticipation in healthy volunteers. International Journal of Neuropsychopharmacology, 12(8), 1009-1020.

Sperli, F., Spinelli, L., Pollo, C., \& Seeck, M. (2006). Contralateral smile and laughter, but no mirth, induced by electrical stimulation of the cingulate cortex. Epilepsia, 47(2), 440443.

Team, R. C. (2018). R: A language and environment for statistical computing. Vienna, Austria: R Foundation for Statistical Computing. Retrieved from https://www.R-project.org/

Vogt, B. A., Berger, G. R., \& Derbyshire, S. W. (2003). Structural and functional dichotomy of human midcingulate cortex. European Journal of Neuroscience, 18(11), 3134-3144.

Wager, T. D., Phan, K. L., Liberzon, I., \& Taylor, S. F. (2003). Valence, gender, and lateralization of functional brain anatomy in emotion: a meta-analysis of findings from neuroimaging. Neuroimage, 19(3), 513-531.

Watson, D., Clark, L. A., \& Tellegen, A. (1988). Development and validation of brief measures of positive and negative affect: the PANAS scales. Journal of personality and social psychology, 54(6), 1063.

Wilson-Mendenhall, C. D., Barrett, L. F., \& Barsalou, L. W. (2013). Neural evidence that human emotions share core affective properties. Psychol Sci, 24(6), 947-956. doi:10.1177/0956797612464242

Winawer, J., \& Parvizi, J. (2016). Linking electrical stimulation of human primary visual cortex, size of affected cortical area, neuronal responses, and subjective experience. Neuron, 92(6), 1213-1219. 
Zald, D. H., \& Pardo, J. V. (1997). Emotion, olfaction, and the human amygdala: amygdala activation during aversive olfactory stimulation. Proceedings of the National Academy of Sciences, 94(8), 4119-4124. 